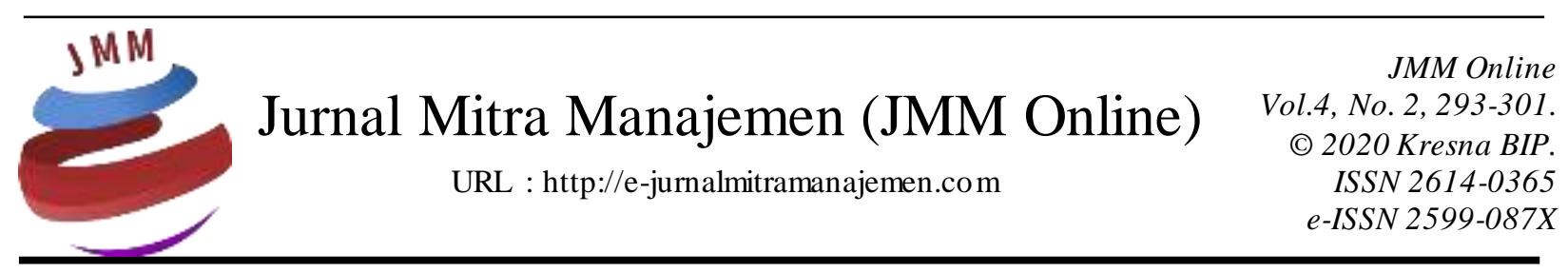

\title{
ANALISIS PEMETAAN E-COMMERCE KECANTIKAN BERDASARKAN BRAND EQUITY
}

\section{Syadza Nadhirah Salsabila 1), AMA Suyanto ${ }^{2)}$ Universitas Telkom}

\section{INFORMASI ARTIKEL}

Dikirim : 14 Februari 2020

Revisi pertama : 17 Februari 2020

Diterima : 19 Februari 2020

Tersedia online : 27 Februari 2020

Kata Kunci : Brand Equity, Positioning Brand, E-Commerce Kecantikan

Email : syadzabila@gmail.com ${ }^{1)}$, amasuyanto@telkomuniversity.ac.id ${ }^{2)}$

\section{ABSTRAK}

Besarnya pengguna aktif sosial media di Indonesia membuat perusahaan memanfaatkan sosial media sebagai tempat untuk melakukan branding. Hal ini banyak dimanfaatkan oleh e-commerce kecantikan dengan gencar melakukan promosi di media sosial. Merek-merek tersebut sedang bersaing dalam benak konsumen dan ecommerce kecantikan tersebut menjual produk dengan karakteristik yang sama. Oleh karena itu, keempat ecommerce kecantikan (Sociolla, Makeupindo, Makeupuccino dan Beautyhaul) harus mampu bersaing untuk menciptakan brand yang kuat di benak konsumen serta membangun brand equity yang kuat pula. Penelitian ini bertujuan untuk memetakan e-commerce kecantikan berdasarkan brand equity.

Penelitian ini menggunakan metode kuantitatif dengan survey kepada 385 responden yang pernah membeli di e-commerce kecantikan Sociolla, Makeupindo, Makeupuccino dan Beautyhaul, dengan metode purposive sampling. Teknik analisis yang digunakan yaitu multidimensional scaling. Hasil dari penelitian menunjukkan bahwa Sociolla berada di peringkat pertama, disusul oleh Makeupuccino pada peringkat kedua, Beautyhaul pada peringkat ketiga dan Makeupindo di peringkat keempat. 


\section{PENDAHULUAN \\ Latar Belakang}

Saat ini, perkembangan teknologi dan informatika semakin pesat salah satunya dengan hadirnya internet yang memberikan dampak positif dalam segala bidang. Jumlah pengguna internet di Indonesia di tahun 2019 mencapai 150 juta pengguna dari total populasi penduduk Indonesia sebesar 268,2 juta penduduk hal ini mengalami kenaikan sebesar 13\% dari tahun 2018 (We Are Social, 2019). Kenaikan tersebut menjadi indikasi bahwa akan ada semakin banyak aspek yang dapat dikembangkan menggunakan internet. Salah satunya berkaitan dengan sosial media, jumlah pengguna aktif sosial media di Indonesia juga mencapai 150 juta pengguna. Selain pengguna sosial media yang semakin aktif dikarenakan besarnya jumlah pengguna internet di Indonesia, dalam bidang bisnis pun internet dapat memudahkan kegiatan berbelanja.

Selama kurun waktu empat tahun terakhir, e-commerce di Indonesia mengalami peningkatan hingga 500 persen. Riset terbaru Google dan temasuk dalam laporan e-Conomy SEA 2018 menunjukkan bahwa ekonomi digital Indonesia tahun 2018 mencapai US\$27 miliar atau sekitar Rp. 391 triliun. Angka tersebut menjadikan transaksi ekonomi digital Indonesia berada di peringkat pertama untuk kawasan Asia Tenggara dengan kontribusi sebesar 49 persen (wartaekonomi.co.id, 2019). Perkembangan e-commerce juga dipicu oleh beragamnya tawaran produk dan jasa layanan online yang menarik, murah dan inovatif. Produk pakaian dan kecantikan merupakan kategori barang yang paling banyak diminati oleh masyarakat di Indonesia dalam belanja online. Penjualan untuk kategori tersebut mencapai US\$ 2,47 miliar sekitar Rp. 32 triliun pada tahun 2018 (databoks.katadata.co.id, 2019). Khususnya, produk kecantikan banyak diminati tidak terlepas dari semakin sadarnya wanita untuk menjaga penampilan. Selain itu, mempercantik diri telah menjadi bagian dari gaya hidup wanita.

Munculnya banyak e-commerce di Indonesia yang menawarkan produk-produk kecantikan lokal maupun internasional membuat persaingan semakin kompetitif. Oleh sebab itu, perusahaan perlu menciptakan brand yang kuat sehingga dapat dikenal oleh konsumen. Besarnya angka pengguna aktif sosial media di Indonesia, membuat perusahaan memanfaatkan sosial media sebagai tempat untuk melakukan pemasaran dan branding, salah satunya Instagram. Instagram menempati posisi keempat dalam platform media sosial teraktif di Indonesia (We Are Social, 2019). Kepopuleran Instagram ini dilihat oleh para pelaku bisnis sebagai peluang yang efektif untuk mempromosikan produk dari usaha mereka.

Dalam penelitian ini penulis hanya menggunakan empat e-commerce kecantikan yang digunakan sebagai objek penelitian karena memiliki followers terbanyak dan memiliki karakteristik yang lengkap. Sociolla, Makeupindo, Makeupuccino dan Beautyhaul memiliki karakteristik yang sama dengan menjual produk makeup terlengkap yang meliputi drugstore makeup, lokal brand makeup, korea brand makeup hingga global brand makeup. Sociolla, Makeupuccino dan Beautyhaul menjual juga produk-produk highend makeup.

Sociolla, Makeupindo, Makeupuccino dan Beautyhaul sama-sama gencar melakukan branding dengan memanfaatkan sosial media. Merek-merek tersebut sedang bersaing dalam benak konsumen terlebih keempat e-commerce kecantikan ini 
menjual produk dengan karakteristik yang sama. Oleh karena itu, keempat e-commerce kecantikan ini harus mampu bersaing untuk menciptakan brand yang kuat di benak konsumen serta membangun brand equity yang kuat pula. Brand equity akan mampu menjadi sumber daya saing bagi perusahaan, jika perusahaan sudah memiliki brand equity yang kuat maka akan mendapatkan nilai tambah bagi perusahaannya di mata konsumen. Tentunya, masing-masing e-commerce kecantikan ini perlu mengetahui posisi brand equity mereka dibandingkan dengan pesaingnya agar dapat memposisikan brandnya secara strategis.

\section{Rumusan Masalah}

Berdasarkan latar belakang yang telah dipaparkan diatas, maka rumusan masalah dalam penelitian ini adalah:

1. Bagaimana pemetaan e-commerce kecantikan berdasarkan brand equity?

2. E-commerce kecantikan mana yang paling unggul berdasarkan brand equity?

\section{Tujuan Penelitian}

1. Untuk mengetahui bagaimana pemetaan e-commerce kecantikan berdasarkan brand equity.

2. Untuk mengetahui e-commerce kecantikan mana yang paling unggul berdasarkan brand equity.

\section{KAJIAN PUSTAKA \\ E-Commerce}

Dikutip dari Laudon dan Traver (2017:8) e-commerce adalah "The use of the internet, the web, and mobile apps and browsers running on mobile devices to transact business". Dari kutipan tersebut dapat diartikan bahwa e-commerce adalah penggunaan internet, web, dan aplikasi seluler dan browser yang berjalan pada perangkat seluler untuk bertransaksi bisnis.

\section{Persepsi}

Menurut Hawkins dan Mothersbaugh (2013:272) persepsi adalah proses yang dimulai dengan paparan konsumen dan perhatian terhadap rangsangan pemasaran dan berakhir dengan interpretasi konsumen. Hal ini juga didukung oleh pendapat Yuniarti (2015:110) yang menyatakan bahwa persepsi adalah proses mengorganisasikan dan memaknakan kesan-kesan indra untuk memberikan arti terhadap lingkungannya. Proses persepsi menurut Hawkins dan Mothersbaugh (2013:272) terbagi menjadi tiga yaitu exposure, attention dan interpretation.

\section{Brand}

Brand dapat didefinisikan sebagai seperangkat atribut berwujud dan tidak berwujud yang dirancang untuk menciptakan kesadaran dan identitas, dan juga untuk membangun reputasi produk, layanan, orang, tempat, atau organisasi (Bonnici, 2015). Dipaparkan oleh Kotler dan Armstrong (2018:264) brand lebih dari sekadar nama dan simbol, brand merupakan elemen kunci dalam hubungan perusahaan dengan konsumen, brand mewakili persepsi dan perasaan konsumen tentang suatu produk dan 
kinerjanya. Hal ini diperkuat dengan pendapat yang dikemukakan oleh Swasty (2016:1) brand bukan hanya sekedar nama dan simbol, brand merupakan cerminan nilai yang produsen atau pemegang merek berikan kepada pelanggan berupa kualitas fisik dan non-fisik dari suatu entitas (perusahaan, produk, jasa dan lain-lain) yang dapat membedakan dirinya dengan yang lain.

\section{Brand Equity}

Dipaparkan oleh Purnatisa dan Suyanto (2019) brand equity adalah bagaimana para brand produk atau jasa memiliki nilai dan kekuatan untuk menciptakan nama brand terkenal di industri pemasaran. Sedangkan menurut Kotler dan Keller (2016:147) brand equity atau ekuitas merek adalah suatu nilai tambah yang diberikan terhadap produk atau jasa yang ditawarkan kepada konsumen. Nilai tambah yang diberikan dapat mempengaruhi pikiran, perasaan dan tindakan terhadap brand tersebut. Hal ini juga didukung oleh pendapat yang disampaikan oleh Swasty (2016:110) bahwa brand equity adalah nilai tambah diberikan pada produk dan layanan. Oleh karena itu, brand equity yang tinggi memungkinkan perusahaan untuk mengurangi biaya pemasaran.

\section{Kerangka Pemikiran}

\section{Gambar 1. Kerangka Pemikiran}

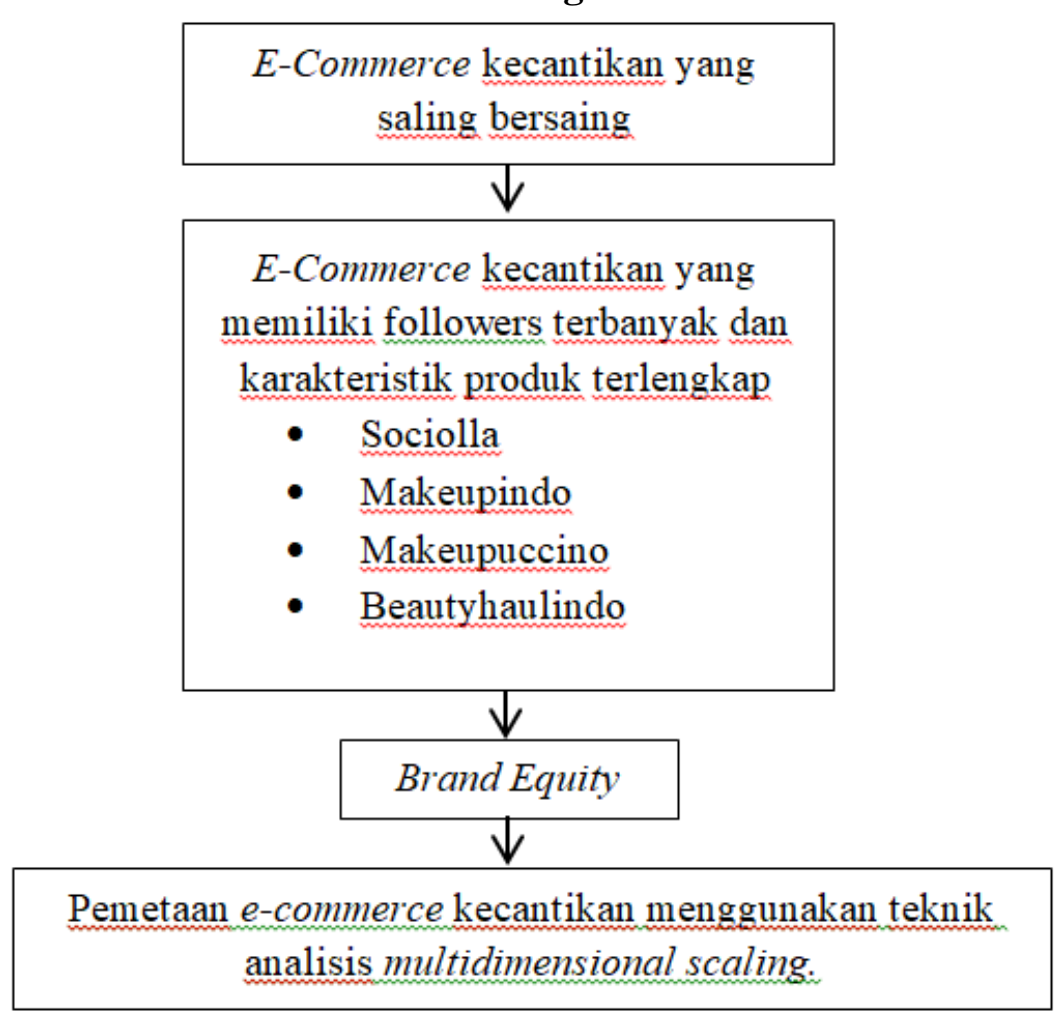

Sumber: Hasil Olahan Penulis (2020) 


\section{METODE PENELITIAN \\ Jenis Penelitian}

Penelitian ini adalah penelitian kuantitatif dengan menggunakan kuesioner sebagai alat pengumpulan data. Teknik sampling yang digunakan adalah nonprobability sampling yaitu purposive sampling. Jumlah sampel sebanyak 385 responden yang pernah membeli di e-commerce kecantikan Sociolla, Makeupindo, Makeupuccino dan Beautyhaul. Skala penelitian ini menggunakan skala ordinal. Skala ordinal dengan mengurutkan atau meranking empat objek e-commerce kecantikan dimulai dari ranking 1 yang merupakan peringkat tertinggi dan ranking 4 merupakan peringkat terendah. Peringkat tersebut menunjukkan urutan penilaian atau tingkat preferensi.

\section{Tempat, Waktu dan Objek Penelitian}

Penelitian ini dilakukan di Indonesia mencakup 19 Provinsi, dengan waktu dan periode penelitian selama 5 bulan yaitu September 2019 hingga Januari 2020. Penelitian ini bertujuan untuk mengetahui bagaimana posisi pemetaan e-commerce kecantikan berdasarkan persepsi masyarakat mengenai brand equity. Penelitian ini dibatasi pada objek penelitian yaitu e-commerce kecantikan Sociolla, Makeupindo, Makeupuccino dan Beautyhaul.

\section{Teknik Pengumpulan Data}

Dipaparkan Sujarweni (2015:103) kuesioner adalah suatu alat untuk mengumpulkan data dalam sebuah penelitian, dalam kuesioner berisi berbagai pertanyaan yang diajukan kepada responden dalam suatu proses penelitian atau survei. Dalam penelitian ini kuesioner disebarkan dengan bantuan google forms yang disebarkan melalui forum online beauty seperti Femaledaily kemudian di media sosial seperti Instagram, Facebook, Youtube, Line, Whatsapp kepada para pencinta makeup seperti beauty vlogger, beauty influencer dan juga makeup artist yang pernah membeli di e-commerce kecantikan Sociolla, Makeupindo, Makeupuccino dan Beautyhaul.

\section{Teknik Analisis Data}

Pengolahan data dalam penelitian ini menggunakan teknik analisis multidimensional scaling (MDS) dengan menggunakan aplikasi SPSS 25. Multidimensional scaling menurut Simamora (2005:234) adalah salah satu prosedur yang digunakan untuk memetakan persepsi dan preferensi para responden secara visual dalam peta geometri.

\section{HASIL PENELITIAN DAN PEMBAHASAN}

Dalam penelitian multidimensional scaling, dimana untuk melihat keandalan dan kesahihan perceptual map yang dihasilkan dapat dilakukan dengan memperhatikan nilai Rsquare yang terdapat pada hasil model perceptual map. Rsquare (RSQ) dalam multidimensional scaling mengindikasikan proporsi varians data input yang dapat dijelaskan oleh model MDS. Semakin tinggi RSQ maka semakin baik model MDS. Menurut Maholtra dalam Simamora (2005:268) model dapat diterima apabila RSQ $\geq$ 0,6 . 
Sedangkan uji reliabilitas menggunakan stress measure. Stress mengindikasikan proporsi varians perbedaan (disparity) yang tidak dijelaskan oleh model. Untuk interpretasi berlaku prinsip "Semakin rendah stress, maka semakin baik model MDS yang dihasilkan". Menurut Maholtra dalam Simamora (2005:269) indikator batasan nilai stress adalah sebagai berikut:

Tabel 2. Indikator Batasan Nilai Stress

\begin{tabular}{|l|l|}
\hline Stress (Percent) & Goodness of Fit \\
\hline 20 & Poor \\
\hline 10 & Fair \\
\hline 5 & Good \\
\hline 2,5 & Excellent \\
\hline 0 & Perfect \\
\hline
\end{tabular}

Sumber: Simamora (2005:269)

Dalam penelitian ini, nilai RSQ yang didapatkan adalah 0,999 dan nilai stressnya adalah 0,024. Berdasarkan nilai RSQ dan stress yang diperoleh dapat disimpulkan bahwa perceptual map yang dihasilkan melalui metode multidimensional scalling (MDS) pada penelitian ini adalah baik. Jika dalam perceptual map tidak terlihat dengan jelas perbedaan letak secara visual, maka dapat menghitung jarak euclidean pada masing-masing merek. Menurut Simamora (2005:283) prinsipnya semakin kecil jarak euclidean, semakin dekat jarak setiap objek maka semakin tinggi pula tingkat persaingannya. Semakin dekat jarak euclidean dengan atribut atau variabel, maka semakin unggul objek terhadap atribut tersebut. Untuk menghitung jarak euclidean, perlu diketahui terlebih dahulu koordinat setiap objek kemudian jarak euclidean dapat dihitung dengan rumus:

$$
\mathrm{Ed}=\sqrt{(x i-x m)^{2}+(y i-y m)^{2}}
$$

Keterangan:

$\mathrm{Ed} \quad=$ Jarak Euclidean (Euclidean distance)

$\mathrm{xi} \quad=$ Absis objek ke-i yang diukur pada dimensi $1(\mathrm{i}=1,2, \ldots, \mathrm{n})$

yi $\quad=$ Ordinat objek ke-i yang diukur pada dimensi $2(i=1,2, \ldots, n)$

$\mathrm{xm}=$ Absis atau posisi atribut pada dimensi 1

$\mathrm{ym}=$ Ordinat atau posisi atribut pada dimensi 2

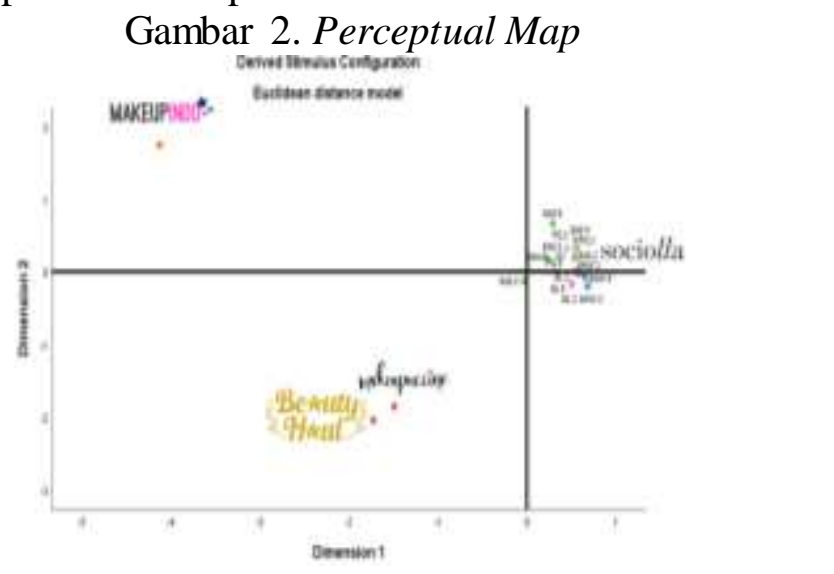

Sumber : Hasil Penelitian, diolah (2020) 
Gambar 2 di atas memperlihatkan perceptual map berdasarkan brand equity. Untuk memperjelas hasil pemetaan dapat dilakukan dengan menghitung jarak geometris atau jarak euclidean untuk masing-masing brand. Hasil dari perhitungan jarak euclidean dapat dilihat pada Tabel 3 berikut ini:

Tabel 3. Perhitungan Jarak Euclidean Posisi Brand Equity

\begin{tabular}{|l|l|}
\hline E-Commerce Kecantikan & Jarak Euclidean Brand Equity \\
\hline Sociolla & 0,324 \\
\hline Makeupindo & 4,904 \\
\hline Makeupuccino & 2,782 \\
\hline Beautyhaul & 3,080 \\
\hline
\end{tabular}

Sumber : Hasil Penelitian, diolah (2020)

Berdasarkan Gambar 2 dan Tabel 3 dapat dilihat bahwa Sociolla lebih dekat terhadap brand equity dengan jarak euclidean terdekat yaitu 0,324 sehingga dapat disimpulkan bahwa Sociolla memiliki keunggulan pada brand equity. Kemudian, Makeupuccino memiliki jarak euclidean terdekat setelah Sociolla yaitu 2,782 akan tetapi Makeupuccino memiliki pesaing terdekat yaitu Beautyhaul dengan jarak euclidean sebesar 3,080 dan berada pada kuadran yang sama, dapat kita lihat pada Gambar 2, posisi Makeupuccino dan Beautyhaul berdekatan sehingga semakin dekat jarak antar posisi merek, semakin tinggi kesamaan yang dimiliki, sehingga persaingan diantara merek tersebut semakin dekat (Simamora, 2005:265). Sedangkan, Makeupindo posisinya berada paling jauh terhadap brand equity dengan jarak euclidean sebesar 4,904, sehingga dapat disimpulkan bahwa Makeupindo masih berada pada posisi yang lemah.

\section{Pembahasan}

Berdasarkan hasil kuesioner yang telah diberikan kepada 385 responden, karakteristik responden dalam penelitian ini sebagian besar berjenis kelamin wanita. Objek penelitian ini merupakan e-commerce kecantikan, seperti kita ketahui bahwa $e$ commerce kecantikan ini menjual produk-produk yang berkaitan dengan kecantikan dan perawatan diri seperti makeup, skincare, dan juga peralatan yang menunjang untuk makeup lainnya dan lebih identik kepada wanita. Sehingga dapat disimpulkan bahwa sebagian besar konsumen e-commerce kecantikan adalah wanita. Kemudian berusia 21-30 tahun dan bertempat tinggal didominasi di pulau Jawa. Dengan latar belakang pendidikan terakhir yaitu SMA/Sederajat dan pekerjaan Pelajar/Mahasiswa kemudian berpenghasilan sebesar < Rp. 3.000.000/ bulan.

Berdasarkan hasil penelitian, Sociolla paling unggul dalam brand equity, hal ini selaras dimana Sociolla telah menjadi e-commerce dengan urutan kedelapan visitor terbanyak di Indonesia pada quartal 3 tahun 2019 dalam situs iPrice (Iprice.co.id, 2019) dan menjadi satu-satunya e-commerce yang fokus menjual produk kecantikan yang masuk kedalam sepuluh besar e-commerce dengan visitor terbanyak. Kemudian pada urutan kedua ditempati oleh Makeupuccino hal ini selaras dengan jumlah pengunjung website Makeupuccino yang lebih banyak dibandingkan Beautyhaul dan Makeupindo, pada tahun 2019 ini pengunjung websitenya 445.300 pengunjung (Statshow.com, 2019) kemudian pada peringkat ketiga ditempati oleh Beautyhaul hal ini pun selaras dengan pengunjung website yang berada dibawah Makeupuccino 
sebanyak 384.710 pengunjung pada tahun 2019 (Statshow.com, 2019) dan pada peringkat keempat ditempati oleh Makeupindo yang memiliki jumlah pengunjung website terendah dibandingkan ketiga e-commerce kecantikan tersebut dengan jumlah 169.360 pengunjung pada tahun 2019 (Statshow.com, 2019) hal ini menunjukkan bahwa brand equity dari Makeupindo masih lemah dibandingkan dengan ketiga $e$ commerce kecantikan lainnya.

\section{KESIMPULAN DAN SARAN \\ Kesimpulan}

Berdasarkan hasil analisis dan pembahasan yang telah dipaparkan, maka dapat diambil kesimpulan penelitian sebagai berikut :

1. Sociolla menempati urutan pertama pada brand equity dengan peringkat terbaik. Disusul oleh Makupuccino menempati peringkat kedua, Beautyhaul menempati peringkat ketiga sedangkan Makeupindo menempati peringkat keempat.

2. Secara keseluruhan, brand e-commerce kecantikan dengan brand equity terbaik adalah Sociolla.

\section{Saran}

1. Saran untuk Perusahaan

a. Sociolla dipersepsikan sebagai e-commerce kecantikan yang menduduki peringkat pertama dan unggul pada brand equity. Oleh karena itu, disarankan Sociolla dapat mempertahankan dan terus mengembangkan keunggulan tersebut.

b. Makeupuccino merupakan pesaing terdekat Beautyhaul. Oleh karena itu, Beautyhaul disarankan untuk memperkuat kembali brand equitynya agar dapat bersaing dengan pesaing terdekatnya yaitu Makeupuccino.

c. Makeupindo disarankan dapat mengembangkan brand equity yang memang harus berbeda dengan yang dimiliki oleh Sociolla maupun dengan Makeupuccino dan Beautyhaul mengingat Makeupindo mempunyai posisi yang jauh dan berada di kuadran tersendiri, tentunya Makeupindo memiliki segmen yang berbeda dengan ketiga e-commerce lainnya. Oleh karena itu, Makeupindo dapat memperkuat brand equitynya pada segmen yg berbeda.

2. Saran Untuk Penelitian Selanjutnya

Saran peneliti untuk penelitian selanjutnya adalah jika melakukan penelitian dengan objek yang sama membahas e-commerce kecantikan dapat menggunakan variabel ataupun atribut yang lain selain brand equity.

\section{DAFTAR PUSTAKA}

Bonnici, T. S. 2015. Brand and Branding. Wiley Encyclopedia of Management. Hawkins, D., \& Mothersbaugh, D. 2013. Consumer Behavior Building Marketing Strategy. New York

Iprice. 2019. The Map of E-commerce in Indonesia. [online]. https:/iprice.co.id/insights/mapofecommerce/en/. [5 Januari 2020] 
Katadata. 2018. Produk Fesyen dan Kecantikan Paling Diminati di Belanja Online.[online].https $/ /$ databoks.katadata.co.id/datapublish/2018/02/07/produksfesyen-dan-kecantikan-paling-diminati-di-belanja-online.[14 September 2019]

Kotler, P., \& Keller, K. L. 2016. A Framework for Marketing Management (6th ed.). England: Pearson Education Limited.

Kotler, P., \& Armstrong, G. 2018. Principles of Marketing (17 ed.). United Kingdom: Pearson Education Limited.

Laudon, K. C., \& Traver, C. G. 2017. E-commerce business, technology, society (13th ed.). USA: Pearson.

Purnatisa, G. P., \& Suyanto, A. 2019. Pengaruh Ekuitas Merek dan Price Premium Terhadap Keputusan Pembelian Smartphone di Indonesia. e-Proceeding of Management, Vol.3, No.1, 263.

Rahayu, N. 2019. Pertumbuhan E-Commerce Pesat di Indonesia. [online]. https://www.wartaekonomi.co.id/read216302/pertumbuhan-e-commerce-pesatdi-indonesia.html. [14 September 2019]

Simamora, B. 2005. Analisis Multivariat Pemasaran. Jakarta: PT. Gramedia Pustaka Utama.

Sujarweni, W. 2015. SPSS Untuk Penelitian. Yogyakarta: Pustaka Baru Press.

Swasty, W. 2016. Branding: Memahami dan Merancang Strategi Merek. Bandung: PT. Remaja Rosdakarya.

Statshow. 2019. StatShow The Stats Maker. [online]. http://www.statshow.com/. [05 Januari 2020]

Wearesocial. 2019. Digital in 2019. [online] https://wearesocial.com/global-digitalreport-2019 [14 September 2019]

Yuniarti, V. S. 2015. Perilaku Konsumen Teori dan Praktik. Bandung: Pustaka Setia. 